\title{
Biochemical Studies on Walls Synthesized by Candida utilis Protoplasts
}

\author{
By MONIQUE NOVAES-LEDIEU \\ AND CONCEPCION GARCIA-MENDOZA \\ Instituto de Biologia Celular, C.S.I.C. Madrid-6, Spain \\ (Accepted for publication I7 February 1970)
}

\begin{abstract}
SUMMARY
Protoplasts of Candida utilis obtained by treatment with helicase built a new wall in a liquid medium. The spherical protoplast was converted to a tubular form which later changed to an ellipsoidal yeast. Walls isolated at different stages of regeneration were analysed. Glucan ( 42 to $48 \%$ ), mannan (25 to $31 \%$ ) and protein ( 8 to $9 \%$ ) were the main constituents of walls of normal and completely regenerated ellipsoidal forms. Walls of the tubular forms differed markedly by having a high content of chitin ( 12 to $18 \%$ ) and of protein $(20 \%)$; mannose was present only as traces. The glucan content was similar in normal, tubular and ellipsoidal regenerating yeasts. These results demonstrate that some modifications occur in the structural polysaccharides of the yeast wall which can be correlated with morphological changes in the reversion process. The significance of glucose, mannose and acetylglucosamine polymers is discussed in relation to the biosynthesis of regenerated walls.
\end{abstract}

\section{INTRODUCTION}

Necas (1956) and Eddy \& Williamson (1959) found that yeast protoplasts were capable, under well defined conditions, of forming new wall structures and of regeneration. However, relatively few chemical studies on this phenomenon have been reported. Recently, Garcia-Mendoza \& Novaes-Ledieu (1968) described the de novo synthesis of wall structures by Candida utilis protoplasts incubated in a liquid medium and noted a high content of chitin in walls of the first regenerating tubular forms. The aim of the present study was to investigate the composition of the wall synthesized newly by protoplasts throughout the regeneration process and to discuss the chemical differences in relation to the morphology.

\section{METHODS}

\section{Growth conditions and preparation of protoplasts}

As in our previous experiments (Garcia-Mendoza \& Novaes-Ledieu, 1968), Candida utilis CECT I06I was grown in Winge medium in a reciprocal shaker at $28^{\circ}$. Yeast was harvested by centrifugation at 10,000'g for Io min., when an optical density of $0 .{ }^{\circ} .600 \mathrm{~m} \mu$ of 0.6 was reached, and washed with distilled water. Then the yeast was washed once with 0.01 M-2-mercaptoethanol in 0.01 M-citrate buffer $(\mathrm{pH} 5.8)$. Treated yeast was washed twice with this buffer, resuspended in the digestion medium containing $0.8 \mathrm{M}$-mannitol in citrate buffer $(\mathrm{pH} 5.8)$, containing I to $2 \mathrm{mg} . / \mathrm{ml}$. dried helicase 
(Industrie Biologique Française, Gennevilliers, France) and shaken at $28^{\circ}$. After $3 \mathrm{hr}$ all the yeast was converted into protoplasts as seen by examination under a phase microscope.

\section{Cultivation of protoplasts in nutrient medium}

Protoplasts prepared from different quantities ( 5 to $100 \mathrm{mg}$. dry wt) of normal yeast, prepared as described above, were washed twice with $0.8 \mathrm{M}$-mannitol, suspended in $500 \mathrm{ml}$. of Winge medium containing $0.55 \mathrm{M}-\mathrm{MgSO}_{4} \cdot 7 \mathrm{H}_{2} \mathrm{O}$ (iso-osmotic for this strain) and incubated at $28^{\circ}$ with gentle shaking. In a series of experiments the initial protoplast inoculum used was minimal (about $5 \mathrm{mg}$. dry wt) and regenerating yeast was collected after 18,30, and $64 \mathrm{hr}$ of incubation. In other series larger amounts of initial protoplast inoculum (about $100 \mathrm{mg}$. dry wt) were used and samples were collected after 4,18 , and $36 \mathrm{hr}$; moreover, regenerating yeasts in their final logarithmic phase (after about $20 \mathrm{hr}$ incubation) were centrifuged and a portion of the deposit was incubated again for 6 or $16 \mathrm{hr}$ in a fresh Winge medium to obtain sufficient yeast at different stages of logarithmic reproduction. During incubation, wall regeneration and cell budding was followed under a phase microscope.

\section{Preparation of walls}

Yeast at different stages of regeneration was collected by centrifugation and treated in a Braun cell homogenizer using no. I2 ballotini beads. To purify the material, the crude wall preparations were suspended several times in 60 and $10 \%$ sucrose in water and centrifuged at $10,000 \mathrm{~g}$ for $20 \mathrm{~min}$. Subsequent treatments with 10 and $\mathrm{I} \%$ $\mathrm{NaCl}$ were performed. Finally, the walls were washed with distilled water and dried in a vacuum.

\section{Analytical methods}

Nucleic acids were estimated from the ultraviolet spectra of extracts obtained by treating samples with $0.5 \mathrm{~N}$-perchloric acid at 75 to $80^{\circ}$ for $30 \mathrm{~min}$. (Gale \& Folkes, 1953). All preparations showing more than $0.5 \%$ nucleic acids were eliminated because they could have been contaminated with cytoplasmic materials.

Protein was determined by the procedure of Lowry, Rosebrough, Farr \& Randall (I95I) performed on cold $\mathrm{N}-\mathrm{KOH}$ extracts of walls: casein was the reference standard.

Amino acids were characterized by chromatography of hydrolysates $(6 \mathrm{~N}-\mathrm{HCl}$ at $105^{\circ}$ for $24 \mathrm{hr}$ ) on Whatman paper no. I ; excess $\mathrm{HCl}$ was removed in vacuum over $\mathrm{NaOH}$. Chromatograms were run for $18 \mathrm{hr}$ with $n$-butanol:formic acid:water $(75: 15: 10, v / v)$; amino acids were detected with ninhydrin $(0.2 \%, w / v)$ in acetone. Three groups of amino acids: arginine, lysine and histidine; aspartic acid, serine and glycine; glutamic acid and threonine were eluted separately with water from chromatograms and characterized by electrophoresis on Whatman no. I paper at $\mathrm{pH}_{6} \mathrm{II} \cdot 5,2 \cdot 25$ and 6.5 respectively.

Neutral carbohydrates were determined using an anthrone reaction (Chung \& Nickerson, 1954). Solutions containing known quantities of glucose and mannose were estimated simultaneously. Identification of monosaccharides was by paper chromatography of hydrolysates prepared in sealed tubes at $105^{\circ}$ with $\mathrm{N}-\mathrm{HCl}$ for 4 and $6 \mathrm{hr}$. Excess $\mathrm{HCl}$ was removed in a desiccator over $\mathrm{NaOH}$. The paper chromatograms (Whatman no.I) were run for $24 \mathrm{hr}$ with $n$-butanol: acetone: water $(4: 5: \mathrm{I}, \mathrm{v} / \mathrm{v})$. Sugars were detected with aniline hydrogen phthalate in $n$-butanol. Semiquantitative deter- 
mination of monosaccharides was made on chromatograms as described by Gottschalk \& Ada (1965).

For total amino sugars, samples were hydrolysed in sealed tubes with $6 \mathrm{~N}-\mathrm{HCl}$ at $105^{\circ}$ for $6 \mathrm{hr}$. The insoluble materials were separated by filtration and $\mathrm{HCl}$ was removed in a vacuum over $\mathrm{NaOH}$ pellets. Neutral sugars, neutral amino acids and condensation products of amino acids were removed by passage of the hydrolysate through a column of Dowex $50-\mathrm{X} 8\left(\mathrm{H}^{+}\right)$resin prepared by the method of Boas (1953), then total hexosamine was determined by the method of Rondle \& Morgan (I955) using glucosamine $\mathrm{HCl}$ as a standard. Amino sugars were resolved by chromatography on Whatman no. I paper with $n$-butanol:pyridine: $0 \cdot 1 \mathrm{~N}-\mathrm{HCl}(5: 3: 2, \mathrm{v} / \mathrm{v})$ as solvent. Hexosamine was located by using a modification of the Elson-Morgan reagent (Partridge, 1948).

For estimation of chitin, yeast walls ( 5 to $10 \mathrm{mg}$.) were shaken for $6 \mathrm{hr}$ at $37^{\circ}$ with $2 \mathrm{mg}$. fungal chitinase (Koch Light) in ammonium acetate buffer $0.03 \mathrm{M} \mathrm{(pH} \mathrm{5.8)}$. Chromatograms on Whatman no. I paper were run with $n$-butanol:acetic acid: water (3: I: I, v/v) for $24 \mathrm{hr}$. N-Acetylglucosamine, chitobiose and chitotriose were detected with diphenylamine trichloroacetate reagent (Hough, Jones \& Wadman, 1950). The intensity of colour and the size of $\mathrm{N}$-acetylglucosamine (NAGA) spot were compared with spots produced by known amounts of standard NAGA. The spots corresponding to chitobiose and chitotriose were eluted from chromatogram with water and hydrolysed with $2 \mathrm{~N}-\mathrm{HCl}$ for $3 \mathrm{hr}$ at $105^{\circ}$. Glucosamine- $\mathrm{HCl}$, liberated by acid hydrolysis, was estimated semiquantitatively on chromatograms (for conditions, see above). Part of the enzymic hydrolysate was dried in a vacuum and then hydrolysed with $2 \mathrm{~N}-\mathrm{HCl}$ for $4 \mathrm{hr}$ at $105^{\circ}$. Excess $\mathrm{HCl}$ was removed by repeated evaporations over $\mathrm{NaOH}$ and the residue was passed through cationic resin (Dowex 50). Glucosamine-HCl was estimated by means of a modification of the method of Rondle \& Morgan as described by Ghuysen, Tipper \& Strominger (1966).

Lipids were isolated by ether extraction after a preliminary treatment with methanol to disrupt any lipoprotein complexes. The extracts were centrifuged to remove traces of suspended material, evaporated and dried in a vacuum over $\mathrm{P}_{2} \mathrm{O}_{5}$.

\section{Solubility of chitin in acids and alkalis}

Samples of yeast walls regenerated for $18 \mathrm{hr}$ were treated for $30 \mathrm{~min}$. with cold $\mathrm{N}-\mathrm{HCl}$, then treated $30 \mathrm{~min}$. at $100^{\circ}$. The residual walls were incubated with $\mathrm{N}-\mathrm{HCl}$ at $100^{\circ}$ for $30 \mathrm{~min}$. Residues and supernatants were dried in a vacuum.

\section{Enzymic treatments of walls of regenerating cells}

Parallel to the chemical studies, regenerating yeasts were treated with helicase or with chitinase and the attack followed under a microscope. Conditions of enzymic digestion were the same as those described above for the treatment of normal yeast and walls.

\section{Enzymic pretreatments of yeast protoplasts}

To eliminate possible contaminants attached to the surface of protoplasts and to study the consequences of this cleaning on successive regenerating phases, the following two procedures were used.

Chitinase treatment: Large amounts of protoplasts prepared with helicase were 
incubated for $3 \mathrm{hr}$ in $0.8 \mathrm{M}-\mathrm{MgSO}_{4} \cdot 7 \mathrm{H}_{2} \mathrm{O}$ in $0.03 \mathrm{M}$-acetate buffer ( $\mathrm{pH} 5.8$ ), and I mg. chitinase $/ \mathrm{ml}$. The reaction mixture was centrifuged and the pellet treated twice more in the same way. The three supernatants were collected and kept to analyse.

Lysozyme treatment. Large amounts of protoplasts prepared with helicase were incubated once for $30 \mathrm{~min}$. in $0.8 \mathrm{M}$-sucrose and $0.05 \mathrm{M}-\mathrm{MgCl}_{2}$ in $0.03 \mathrm{M}$-tris- $\mathrm{HCl}$ $(\mathrm{pH} 7 \cdot 5)$ and $200 \mu \mathrm{g}$. lysozyme $/ \mathrm{ml}$.

Controls without enzyme were included. Both preparations of protoplasts were washed to eliminate the residual enzymes and inoculated in reversion medium as described above.

\section{RESULTS}

\section{Chemical analyses}

Examination under a light microscope of different stages of protoplast regeneration showed that all the initially spherical protoplasts showed signs of growth, seeming to* bud after 2 to $4 \mathrm{hr}$; afterwards they changed to tubular forms from which new normal

Table I. Chemical composition of Candida utilis walls

About $5 \mathrm{mg}$. protoplasts were inoculated in $500 \mathrm{ml}$. Winge medium.

\begin{tabular}{|c|c|c|c|c|}
\hline & $\begin{array}{c}\text { Normal } \\
\text { cells } \\
24 \text { hr growth }\end{array}$ & $\begin{array}{c}\text { I8 hr re- } \\
\text { generating } \\
\text { cells* (tubular } \\
\text { h form) }\end{array}$ & $\begin{array}{c}30 \mathrm{hr} \text { re- } \\
\text { generating } \\
\text { cells } \uparrow \text { (yeast } \\
\text { form) }\end{array}$ & $\begin{array}{l}64 \mathrm{hr} \text { re- } \\
\text { generating } \\
\text { cells } \ddagger \text { (yeast } \\
\text { form) }\end{array}$ \\
\hline Total carbohydrate (anthrone) & $78-80$ & $50-5 I$ & $75-78$ & $78-79$ \\
\hline Glucose & 48 & 48 & 46 & 47 \\
\hline Mannose & 30 & $1-2$ & 29 & 30 \\
\hline $\begin{array}{l}\text { Total hexosamine (Rondle \& } \\
\text { Morgan) }\end{array}$ & $0.2-0.5$ & 16 & $2-3$ & $2-3$ \\
\hline Protein (Lowry) & $8-9$ & 20 & 9 & 9 \\
\hline Chitin (chitinase) & $0.1-0.2$ & I8 & $I-3$ & $1-2$ \\
\hline Free and bound lipids (gravi- & I & $0.5^{-1}$ & 1 & I \\
\hline
\end{tabular}

\footnotetext{
* Logarithmic phase yeast.

$\dagger$ Final logarithmic phase yeast.

$\ddagger$ Stationary phase yeast.
}

shaped yeasts later originated. A homogeneous population of ellipsoidal-shaped yeast was not complete until after 30 to $36 \mathrm{hr}$ of incubation although the first ellipsoidal forms appeared after 20 to $24 \mathrm{hr}$.

Garcia-Mendoza \& Novaes-Ledieu (1968) showed the composition of walls of tubular forms ( $18 \mathrm{hr}$ incubation) to be very different from that of the parent yeast. These results have been confirmed (see Table $\mathrm{I}$ ): a high content of chitin ( $18 \%$ ) and a small amount of mannose were found in the tubular form. Normal yeast walls contained large amounts of mannose and small amounts of chitin. The samples between 20 and $30 \mathrm{hr}$ incubation were discarded because the cultures were showing a heterogeneous appearance.

In contrast with the above finding, the wall material from minimal inocula, prepared from final logarithmic phase cells (after $30 \mathrm{hr}$ incubation) and stationary phase cells (64 hr incubation) had a composition grossly similar to that of normal yeast (Table I).

Walls of $4 \mathrm{hr}$ regenerating yeast were therefore analysed. Preliminary experiments 
performed with these structures showed three principal components: glucan, protein and chitin (this last over $12 \%$ ). This suggested that a complex of glucan plus chitin could be formed during the early stage of wall biosynthesis.

Wall material, from large inocula, prepared from stationary-phase yeast from the $36 \mathrm{hr}$ culture differed largely from material obtained above with $30 \mathrm{hr}$ walls (see Tables I, 2). In the former there was as high a proportion of mannose as in normal walls, but the chitin content remained approximately the same as that in tubular forms, possibly as a consequence of the exhausted medium, so there were few opportunities for the regenerating yeast to bud. In these preparations the protein content was reduced to the value of normal yeast walls. Chemical analyses of logarithmic phase yeast walls ( $20 \mathrm{hr}$ plus $6 \mathrm{hr}$, and $20 \mathrm{hr}$ plus $\mathrm{r} 6 \mathrm{hr}$ ), both from ellipsoidal cells, revealed compositions similar to that of normal yeast walls, suggesting that the newly formed generation contained only traces of chitin, as in normal walls.

Table 2. Chemical composition of Candida utilis walls About $100 \mathrm{mg}$. protoplasts were inoculated in $500 \mathrm{ml}$. of Winge medium.

\begin{tabular}{|c|c|c|c|c|c|}
\hline & $\begin{array}{l}\text { Normal } \\
\text { cells } 24 \mathrm{hr} \\
\text { growth }\end{array}$ & $\begin{array}{l}\text { I8 hr re- } \\
\text { generating } \\
\text { cells* } \\
\text { (tubular } \\
\text { form) }\end{array}$ & $\begin{array}{c}36 \mathrm{hr} \text { re- } \\
\text { generating } \\
\text { cells† } \\
\text { (yeast } \\
\text { form) }\end{array}$ & $\begin{array}{l}20+6 \mathrm{hr} \\
\text { regenerat- } \\
\text { ing cells } \ddagger \\
\text { (yeast } \\
\text { form) }\end{array}$ & $\begin{array}{c}20+16 \mathrm{hr} \\
\text { regenerat- } \\
\text { ing cells } \ddagger \\
\text { (yeast } \\
\text { form) }\end{array}$ \\
\hline Total carbohydrate (anthrone) & $78-80$ & $50-5 \mathrm{I}$ & $65-68$ & $78-80$ & $78-80$ \\
\hline Glucose & 48 & 48 & 42 & 48 & 48 \\
\hline Mannose & 3I & $\mathrm{I}-2$ & 25 & 30 & 30 \\
\hline $\begin{array}{l}\text { Total hexosamine (Rondle \& } \\
\text { Morgan) }\end{array}$ & $0.2-0.5$ & I6 & 16 & $I-I \cdot 2$ & $0.4-0.8$ \\
\hline Protein (Lowry) & $8-9$ & 20 & 9 & 9 & 9 \\
\hline Chitin (chitinase) & $0.1-0.2$ & 18 & 18 & $I \cdot 5-I \cdot 8$ & $0.3-0.5$ \\
\hline $\begin{array}{l}\text { Free and bound lipids (gravi- } \\
\text { metrically) }\end{array}$ & 1 & $0.5-I$ & $0.5-1$ & $0.6-1$ & $0.5-1$ \\
\hline
\end{tabular}

Analyses of the various stages of regenerated yeast walls and normal walls have shown that all the usual amino acids were present and in similar proportions. The $\mathrm{MgSO}_{4} \cdot 7 \mathrm{H}_{2} \mathrm{O}$ in the regeneration medium did not have an influence on the growth of yeast and on the composition of walls because analyses of normal cell walls incubated in Winge medium and in the same medium but containing $\mathrm{MgSO}_{4}$ were similar.

\section{Solubility of regenerated cell walls in acids and alkalis}

Treatment with $\mathrm{N}-\mathrm{HCl}$, in cold and at $100^{\circ}$ solubilized only a small portion of tubular walls. The soluble material corresponded to 15 to $20 \%$ of total wall and was glucan and protein. In the insoluble part an acid-insoluble glucan and the chitin were found. Treatment of the residue with $\mathrm{N}-\mathrm{KOH}$ at $100^{\circ}$ dissolved the glucan alone, the glucosamine polymer being extraordinarily resistant toward acid and alkali. In normal walls, $70 \%$ of anthrone-positive products were soluble in hot $\mathrm{HCl}$.

\section{Effect of selected enzymes on regenerated walls}

Phase-microscope examination showed that the walls of $18 \mathrm{hr}$ tubular forms treated with helicase were damaged to some degree and that a small proportion of these 
tubes were transformed into protoplasts. Treatment with chitinase damaged the wall structures to a lesser degree. Regenerating ellipsoidal cells harvested during the logarithmic phase of growth ( $30 \mathrm{hr}$ incubation, $20 \mathrm{hr}$ plus $6 \mathrm{hr}$ incubation, or $20 \mathrm{hr}$ plus $\mathrm{I} 6 \mathrm{hr}$ incubation) and treated with helicase were markedly attacked, giving a high percentage of protoplasts, suggesting that the carbohydrate chains present in their walls are similar to those in normal cells. As was expected, treatment with chitinase did not appear to affect the wall structure.

\section{Regeneration of enzymic pretreated protoplasts}

After pretreatment with chitinase, examination under a phase microscope showed that protoplasts had difficulties in building a new wall. Growth was slower and after I $8 \mathrm{hr}$ incubation in the usual conditions, numerous protoplasts were observed; these were often deformed but without clear appearance of reversion. Some tubular forms with thick and less compact walls were also encountered. After $24 \mathrm{hr}$ incubation the preparations appeared more normal, showing a high percentage of tubular forms. The first yeast forms were observed after 40 to $44 \mathrm{hr}$ incubation. Cultures which had regenerated for $18 \mathrm{hr}$ and $24 \mathrm{hr}$ presented generally a heterogeneous picture, thus making it difficult to obtain a pure preparation of tubular form walls. However, preliminary chemical analyses were carried out on samples of walls obtained from tubular yeasts and from $36 \mathrm{hr}$ regenerating yeasts (stationary phase forms described in Table 2). We expected that both walls would be rich in chitin; however, the chitin content was lower than that expected.

Microscopic examination showed that pretreatment with lysozyme also interfered with reversion of protoplasts. Estimation of chitin in the walls of $18 \mathrm{hr}$ tubular forms and $36 \mathrm{hr}$ regenerating ellipsoidal yeasts (stationary phase forms described in Table 2) gave percentages lower than those found when protoplasts were incubated without pretreatment with lysozyme.

\section{DISCUSSION}

Protoplasts of our strain of Candida utilis synthesized walls de novo despite earlier reports that a solid medium was necessary for regeneration of protoplasts of yeasts whose walls contain mannan. Protoplasts of mannan-free yeasts regenerate either in liquid or on solid media (Svoboda, 1965; Necas \& Svoboda, 1965). The composition of the regeneration medium is probably important; presumably the osmotic stabilizer plays a role preventing leakage of intermediates of mannan synthesized extracellularly (Kozak \& Bretthauer, 1968). This may be one reason why Eddy \& Williamson (1959) did not obtain reversion of protoplasts of Saccharomyces carlsbergensis, though they observed tubular forms like those we saw. Alternatively, their regeneration medium may have been nutritionally inadequate.

The walls of Candida utilis, when fully regenerated, had the chemical constitution of normal walls, but the intermediate tubular forms were rich in glucan and chitin but deficient in mannan. Mannan formation was associated with restoration of the normal ellipsoid form. We suggest, therefore, that primary formation of a glucanchitin matrix gives the organism rigidity and provides a basis for mannan deposition, which confers the ellipsoid form. This view is consistent with Bartnicki-Garcia \& Nickerson's (1962) report of extra mannan in walls of yeast-like forms of Mucor rouxii and with Chattaway, Holmes \& Barlow's (1968) report that the mycelial form 
of $C$. albicans is relatively rich in chitin. Chitin formation is associated with budding in yeasts (Bacon, Davidson, Jones \& Taylor, 1966; Bacon, Jones \& Ottolenghi, 1969).

The glucan-chitin matrix is probably identical with the fibrilar network revealed by electron microscopy of early regenerating protoplasts (Kopecka, Ctrvrtnicek \& Necas, 1965; Necas, Svoboda \& Havelkova, 1968; Uruburu, Elorza \& Villanueva, 1968) and previously believed to be composed of glucan; it is presumably closest to the protoplast membrane in the normal yeast.

The regenerating protoplasts in our work and in other reports probably possessed residual wall components which acted as primers for synthesis of new polymer (Glaser \& Brown, I957; Garcia-Mendoza, Garcia Lopex, Uruburu \& Villanueva, 1968; Streiblova, 1968; Bacon et al. 1969; Darling, Theilade \& Birch-Andersen, 1969). The delaying effect on regeneration of pretreatment with lysozyme or chitinase is probably due to removal of primer by these enzymes (Cherkazov \& Kravchenko, 1968).

\section{REFERENCES}

Bacon, J. S. D., Davidson, E. D., Jones, D. \& TaYlor, I. F. (1966). The location of chitin in the yeast cell wall. Biochemical Journal ror, $36 \mathrm{c}-38 \mathrm{c}$.

BACON, J. S. D., JoNES, D. \& OTTOLENGHi, P. (1969) Cell wall residues in yeast protoplast preparations. Journal of Bacteriology 99, 885-887.

BartnICKI-Garcta, S. \& Nickerson, W. J. (I962). Isolation, composition and structure of cel walls of filamentous and yeast-like forms of Mucor rouxii. Biochimica et Biophysica Acta 58 , 102-119.

BoAs, N. F. (1953). Method for the determination of hexosamines in tissues. Journal of Biologica Chemistry 204, 553-563.

Chattaway, F. W., Holmes, M. R. \& Barlow, A. J. E. (1968). Cell wall composition of the mycelial and blastospore forms of Candida albicans. Journal of General Microbiology 5r, 367-376.

Cherkazov, I. A. \& Kravchenko, N. A. (1968). On some features of the sorbtion of lysozyme on chitin. Biokymia 33, 76I-765. (In Russian.)

Chung, C. W. \& Nickerson, W. J. (I954). Polysaccharide synthesis in growing yeasts. Journal of Biological Chemistry 208, 395-407.

Darling, S., Theilade, J. \& BirCh-ANDERSEn, A. (1969). Kinetic and morphological observations on Saccharomyces cerevisiae during spheroplast formation. Journal of Bacteriology 98, 797-810.

EdDY, A. A. \& Williamson, D. H. (1959). Formation of aberrant cell walls and of spores by the growing yeast protoplasts. Nature, London 183 , I IOI-I I04.

Gale, E. F. \& FolKEs, J. P. (1953). The assimilation of amino acids by bacteria. Nucleic acids and protein synthesis in Staphylococcus aureus. Biochemical Journal 53, 483-492.

Garcia-Mendoza, C., Garcia Lopez, M. D., Uruburu, F. \& Villanueva, J. R. (1968). Structural and immunological studies on the protoplast membrane of the yeast Candida utilis. Journal of Bacteriology 95, 2393-2398.

Garcta-MendozA, C. \& Novaes-Ledieu, M. (1968). Chitin in the new wall of regenerating protoplasts of Candida utilis. Nature, London 220, I035.

Ghuysen, J. M., TipPer, D. J. \& Strominger, J. L. (1966). Enzymes that degrade bacterial cell walls. Methods in Enzymology 8, 685-699.

Glaser, L. \& Brown, D. H. (1957). Synthesis of chitin in cell-free extracts of Neurospora crassa. Journal of Biological Chemistry 228, 729-742.

GotTsCHALK, A. \& ADA, G. L. (1956). The separation and quantitative determination of the component sugars of mucoproteins. Biochemical Journal 62, 68I-686.

HOUGH, L., JONES, J. K. N. \& WADMAN, W. (1950). Quantitative analysis of mixtures of sugars by the method of partition chromatography. V. Improved methods for the separation and detection of the sugars and their methylated derivatives on the paper chromatogram. Journal of the Chemical Society 2, 1702-1 706. 
KopeCKA, M., CTRVRTNICEK, O. \& NeCAS, O. (1965). Formation and properties of fibrillar network formed in yeast protoplasts as the first step of biosynthesis of cell wall. Symposium über HefeProtoplasten, pp. 73-75. Edited by R. Müller. Berlin: Akademie-Verlag.

KozAK, L. P. \& BRETTHAUER, R. K. (1968). Synthesis of exocellular phosphomannan by protoplasts of Hansenula holsti. Archives of Biochemistry and Biophysics 126, 764-770.

Lowry, O. H., Rosebrough, N. J., Farr, A. L. \& Randall, R. J. (195I). Protein measurement with the Folin phenol reagent. Journal of Biological Chemistry 193, 265-275.

NeCAS, O. (1956). Regeneration of yeast cells from naked protoplasts. Nature, London 177, 898-899.

NeCAS, O. \& Svoboda, A. (1965). Relation between the biosynthesis of the cell wall and regeneration in yeast protoplasts. Symposium über Hefe-Protoplasten, pp. 67-71. Edited by R. Müller. Berlin: Akademie-Verlag.

Necas, O., Svoboda, A. \& Havelkova, M. (1968). Mechanism of regeneration of yeast protoplasts. V. Formation of the cell wall in Schizosaccharomyces pombe. Folia Biologica, Prague 14, 80-85.

PARTRIDGE, S. M. (1948). Filter-paper partition chromatography of sugars. Biochemical Journal 42, 238-248.

RoNDLE, C. J. M. \& MoRGAN, W. T. J. (1955). The determination of glucosamine and galactosamine. Biochemical Journal 61, 586-589.

STREIBLOVA, E. (1968). Surface structure of yeast protoplasts. Journal of Bacteriology 95, 700-707.

SvoвоDA, A. (1965). Regeneration ability of protoplasts of different yeast species. Symposium über Hefe-Protoplasten, pp. 3I-35. Edited by R. Müller. Berlin: Akademie-Verlag.

URUBURU, F., EloRZA, V. \& VILLANUEVA, J. R. (1968). The fine structure of yeast regenerating protoplasts. Journal of General Microbiology 5I, 195-198. 